\title{
Pengembangan Array sensor Suhu dan Sistem Akusisi Data Berbasis Mikrokontroler untuk Pengukuran Suhu Bawah Permukaan
}

\author{
Verna Albert Suoth ${ }^{*}{ }^{*}$, Didik R. Santoso ${ }^{b}$, Sukir Maryantob \\ aJurusan Fisika, FMIPA, Unsrat, Manado \\ bJurusan Fisika, FMIPA, Universitas Brawijaya, Malang
}

\author{
KATA KUNCI \\ Sensor LM35 \\ RS-485 \\ Mikrokontroler \\ RTU-MTU
}

\begin{abstract}
A B S T R A K
Dalam penelitian ini dikembangkan sebuah sistem akusisi data untuk survei panas bumi. Untuk menghasilkan sistem instrumentasi yang mampu mengukur dan memonitor distribusi suhu bawah permukaan diperlukan sistem akusisi data yang murah dan efesien. Sistem dibangun berbasis jaringan sistem terdistribusi dengan topologi field-bus, menggunakan arsitektur single-master multi-slave. Master merupakan unit pengendali, dibangun berbasiskan sebuah PC yang dilengkapi dengan antarmuka RS-485. Slave merupakan unit sensing, tiap-tiap unit slave dibangun dengan mengintegrasikan sistem array sensor LM35 dengan sistem akuisisi data berbasis mikrokontroler menggunakan AVR ATmega8. Pengolahan data dari hasil pengukuran suhu ini menggunakan satu set komputer dengan perangkat lunak microsoft excel 2010 untuk menghasilkan grafik pada titik pengukuran. Hasil implementasi dari monitoring suhu ini akan mengambarkan distribusi suhu bawah permukaan tanah.

A B S T R A C T
A data acquisition system for geothermal survey was developed in
this research. Cheap and efficient data acquisition system was required to
produce the instrumentation system which was capable to measure and
monitor the distribution of subsurface temperature. The system consists of
field-bus topology, using single-master multi-slave architecture. Master is a
control unit built based on a PC equipped with RS-485 interface. Slave is a
sensing unit; each slave is built by integrating array sensor LM35 within
AVR ATmega8a microcontroller-based data acquisition system.
Measurement techniques included sounding and mapping system by
placing four slaves planted in the depth of 2.5 m. Processing of data
obtained from temperature measurements was performed using Microsoft
Excel 2010 to produce graphics at point of measurement. The results of
temperature monitoring will described the distribution of subsurface
temperature.
\end{abstract}

AVAILABLE ONLINE

12 February 2013
Microcontroller

RTU-MTU 
merupakan sensor suhu yang akurat dimana tegangan keluarannya berbanding lurus dengan suhu dalam derajat celcius sebesar $10 \mathrm{mV} /{ }^{\circ} \mathrm{C}$ (Datasheet LM35, 2000; Cheeke, 2007). Sistem instrumentasi ini dibangun di atas dua unit utama, yaitu Remote Terminal Unit (RTU) sebagai unit slave dan Master Terminal Unit (MTU) sebagai unit master (Santoso, 2010). Unit slave ini merupakan penginderaan pada unit sensor yang dilengkapi dengan sistem akuisisi data berbasis mikrokontroler. Unit master dibangun berdasarkan PC, dan menginstal perangkat lunak aplikasi untuk data logger, memungkinkan pengguna mengetahui suhu bawah permukaan tanah dari aktivitas panas bumi yang dipantau secara real time. Fungsi kerja slave sepenuhnya dikontrol oleh unit master (Santoso, et al., 2012).

Komunikasi secara serial (serial communications) merupakan cara menghantar data yang lebih mudah dibandingkan komunikasi paralel (parallel communications) disebabkan sistem komunikasi paralel terlalu mahal untuk kegunaan jarak jauh.Salah satu standart komunikasi serial yang dipakai adalah Teknik RS-485, Teknik ini adalah teknik komunikasi data serial yang dapat dilakukan pada jarak yang cukup jauh yaitu 1,2 Km dan dapat digunakan untuk menghubungkan 32 unit beban. Standard RS-485 mendukung komunikasi data halfduplex, ini berarti bahwa untuk mengirimkan dan menerima data hanya menggunakan 2 jalur kabel (Axelson, 1998; Vitria, 2008).

Penelitian ini sebelumnya dikembangkan oleh Arif Ismul Hadi dan Refrizon (2005), dalam penelitiannya adalah mengukur suhu bawah permukaan untuk menghasilkan model distribusi namun sistem diterapkan masih menggunakan sistem pengukuran manual, dengan mengukur suhu secara langsung pada kedalaman $75 \mathrm{~cm}$. Dengan demikian tidak efektif untuk kebutuhan pengukuran suhu di banyak titik pengukuran. Atas dasar permasalahan ini maka seiring dengan pesatnya perkembangan teknologi instrumentasi saat ini, maka dikembangkan sistem instrumentasi menggunakan arsitektur sistem terdistribusi. Sistem terdistribusi merupakan kumpulan beberapa sensor suhu yang terhubung melalui sistem jaringan terintegrasi. Sistem pengukuran terdistribusi yaitu sistem terbuka yang dapat menghasilkan sensor dalam satu payung, artinya sistem ini dapat melakukan pengukuran secara simultan (Santoso, 2005).

\section{Bahan dan Metode}

Metodologi yang dilakukan pada penelitian ini meliputi studi literatur guna memperoleh informasi pada penelitian-penelitian sebelumnya dan mencari referensi pendukung dalam penelitian yang akan dilakukan. Langkah selanjutnya adalah mendesain dan membuat sistem instrumentasi pengukuran suhu yang ingin diharapkan, setelah alat telah jadi kemudian diuji. Pengujian dilakukan dua kali, yang pertama dengan membandingkan hasil pengukuran suhu dengan termometer dan yang kedua pengujian dilapangan dengan membandingkan hasil pengukuran suhu pada daerah beranomali panas bumi dan daerah yang tidak beranomali panas bumi. Diagram alir penelitian seperti pada Gambar 1.

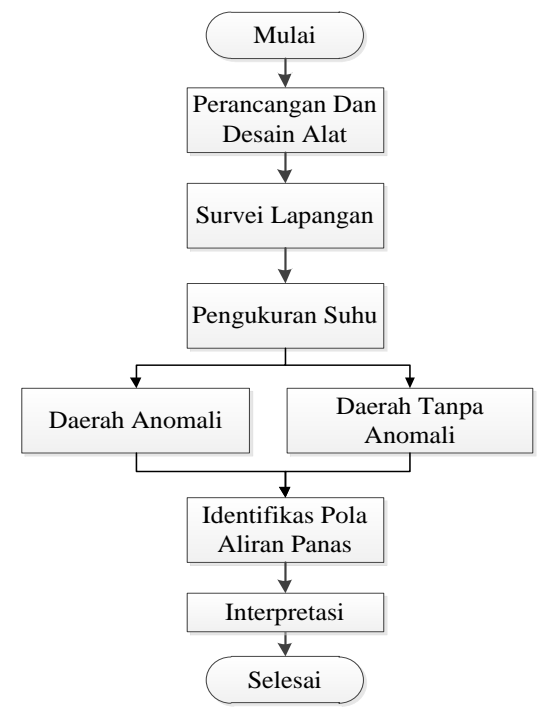

Gambar 1. Diagram alir penelitian.

\subsection{Perancangan Dan Desain Sistem Intrumentasi}

Perancangan sistem instrumentasi terdiri dari empat bagian utama, yaitu:

1. Bagian Slave, berfungsi sebagai sensor suhu yang mendeteksi keadaan suhu bawah permukaan tanah. Informasi yang diambil adalah kondisi temperatur dengan menggunakan LM35. Setiap data yang diambil berukuran 8 bit. Pengambilan data dilakukan setelah mendapatkan perintah, kemudian menunggu pengambilan data hingga selesai. Setelah itu data akan diolah oleh mikrokontroler menggunakan ATmega8 dan dikirim menuju master dengan menggunakan serial RS-485.Setiap melakukan pengukuran diletakkan empat Slave. Modul slave terdiri dari sensor LM35, pengkondisi Perancangan modul slave seperti Gambar 2

2. Bagian Master, berfungsi sebagai komunikasi data dari master ke komputer. Perancangan modul master ditunjukkan pada Gambar 3, modul master ini terdiri dari rangkaian konverter RS-485 ke RS-232 dan Rangkaian power supply.Master menerima data dari empat slave. Komunikasi data dari Master ke slave menggunakan serial RS-485. Untuk komunikasi menuju komputer, Master menggunakan konverter 485 ke 232. Hal ini disebakan komputer tidak mampu membaca sinyal RS 485 sehingga diperlukan pengubah sinyal dari RS-485 ke RS-232.

3. Bagian Data Base dan Penampil, bagian ini dibuat menggunakan software Delphi yang dirancang sebagai penampil data hasil pengukuran suhu, 
software ini juga berfungsi untuk menyimpan data dan mengolah data dari Master. Hasil pengukuran ini nantinya akan menghasilkan informasi suhu bawah permukaan tanah. Selain itu, dengan adanya data base, dapat membantu menyediakan informasi suhu secara real time.

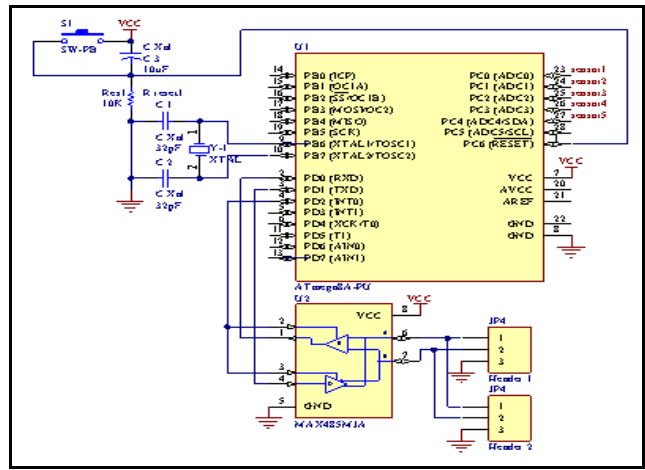

(a)

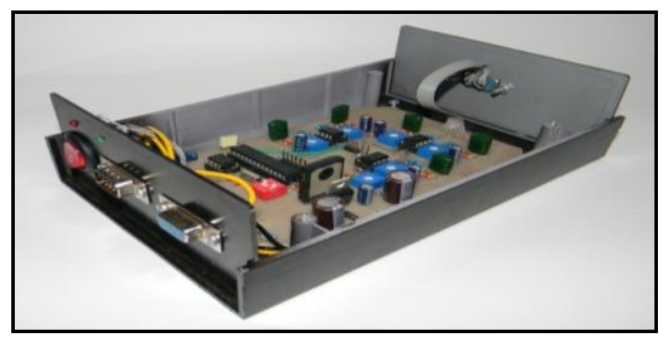

(b)

Gambar 2. (a). Rangkaian Schematic modul Slave; (b). Modul Slave hasil perancangan

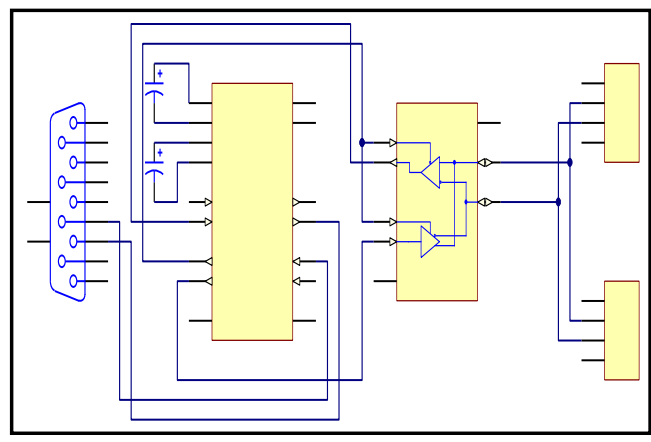

(a)

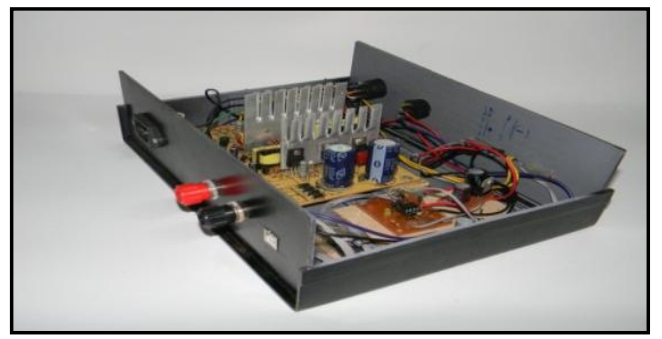

(b)

Gambar 3. (a). Rangkaian Schematic modul Master; (b). Modul Master hasil perancangan

Sistem intrumentasi digambarkan pada Gambar 4.. Sistem intrumentasi dibagi dalam empat unit.
Pertama, sensor yang berfungsi mengukur suhu bawah permukaan tanah menggunakan LM35. Kedua, pengkondisi sinyal yang berfungsi mengkondisikan sinyal dari sensor agar sesuai dengan kebutuhan sinyal untuk mikrokontroler. Ketiga, akusisi data yang berfungsi mengambil, mengumpulkan dan menyiapkan data, hingga memprosesnya untuk menghasilkan data yang di kehendaki. Keempat, Penampil/display, yang berfungsi untuk menampikan hasil pengukuran (Sahara, 2011).

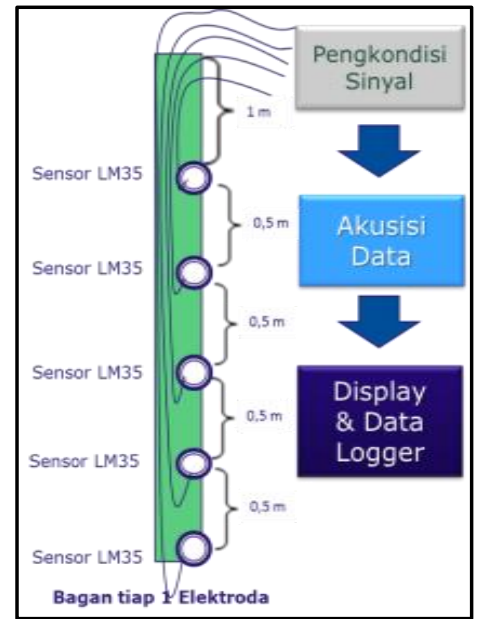

Gambar 4. Sistem instrumentasi

\section{2 Prosedur Penelitian}

Untuk pengambilan data pada pusat sumber mata air panas, terlebih dahulu dilakukan pemetaan dengan membuat lintasan disekitar pusat sumber mata air panas yang akan dijadikan tempat melakukan penelitian. Pengukuran suhu dilakukan setelah lubang dianggap stabil dan dilakukan pada pagi hari untuk menghindari pengaruh panas matahari, terutama untuk lokasi yang terbuka atau terkena sinar matahari secara langsung. Metode pengambilan data seperti pada Gambar 5.

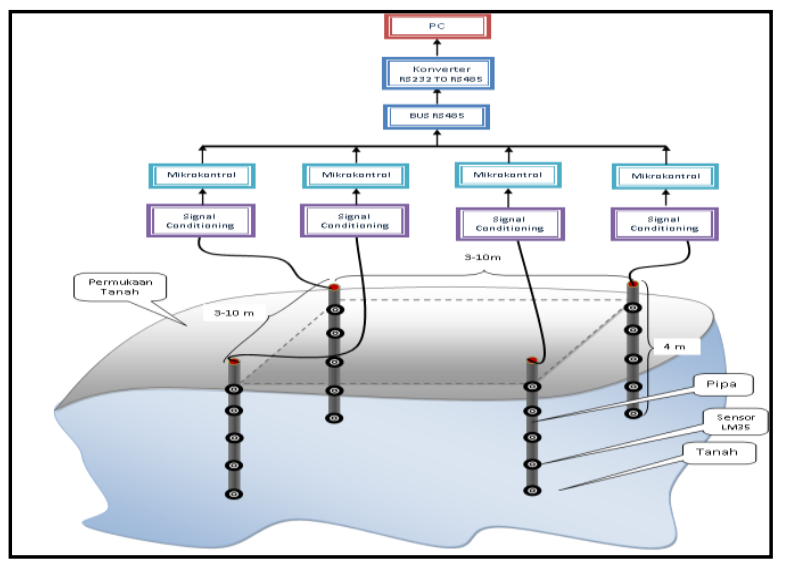

Gambar 5. Metode pengambilan data. 
Pengambilan data dilakukan secara mapping dan sounding dengan meletakkan 4 buah sensor elektroda dibawah permukaan tanah membentuk Grid A,B,C. Jarak antar elektroda 6 meter. Titik pengukuran dipilih pada pusat yang sangat panas yang memiliki tingkat yang paling panas. Sensor dimasukkan ke dalam lubang yang telah dilubangi. Data suhu yang telah diperoleh dari lapangan diolah dengan menggunakan microsoft excel guna mendapatkan gradien suhu. Untuk mendapatkan model 3 dimensi digunakan software Surfer.

\section{Hasil dan Pembahasan}

\subsection{Pengujian Sistem Keseluruhan}

Pengujian sistem keseluruhan dilakukan dengan menempatkan sensor LM35 dan termometer dalam plat suhu yang sama kemudian membandingkan antara suhu penunjukan yang tertampil pada tampilan komputer terhadap penunjukan suhu pada termometer. Hasil pengujian sistem ditampikan pada Tabel 1

Tabel 1. Hasil pengujian sistem

\begin{tabular}{|c|c|c|}
\hline Suhu & $\begin{array}{c}\text { Tampilan } \\
\text { suhu pada } \\
\text { monitor }\end{array}$ & $\begin{array}{c}\text { Selisi } \\
\text { pengukuran }\end{array}$ \\
\hline $30^{\circ} \mathrm{C}$ & $29,7^{\circ} \mathrm{C}$ & $0,3^{\circ} \mathrm{C}$ \\
$32^{\circ} \mathrm{C}$ & $32,0^{\circ} \mathrm{C}$ & $0,0^{\circ} \mathrm{C}$ \\
$34^{\circ} \mathrm{C}$ & $34,0^{\circ} \mathrm{C}$ & $0,0^{\circ} \mathrm{C}$ \\
$37^{\circ} \mathrm{C}$ & $37,5^{\circ} \mathrm{C}$ & $0,5^{\circ} \mathrm{C}$ \\
$40^{\circ} \mathrm{C}$ & $40,0^{\circ} \mathrm{C}$ & $0,0^{\circ} \mathrm{C}$ \\
$45^{\circ} \mathrm{C}$ & $45,0^{\circ} \mathrm{C}$ & $0,0^{\circ} \mathrm{C}$ \\
$46^{\circ} \mathrm{C}$ & $46,0^{\circ} \mathrm{C}$ & $0,0^{\circ} \mathrm{C}$ \\
$47^{\circ} \mathrm{C}$ & $46,5^{\circ} \mathrm{C}$ & $0,5^{\circ} \mathrm{C}$ \\
\hline
\end{tabular}

Gambar 6 menunjukkan grafik dari pengujian sistem keseluruhan pada pengukuran dua variabel yang terkait satu sama lain, secara linear dapat ditulis bentuk persamaan linearnya (Bevinton dan Robinson, 1992):

$$
\begin{aligned}
& Y=a X+b \\
& Y=0,9793 X+0,7055
\end{aligned}
$$

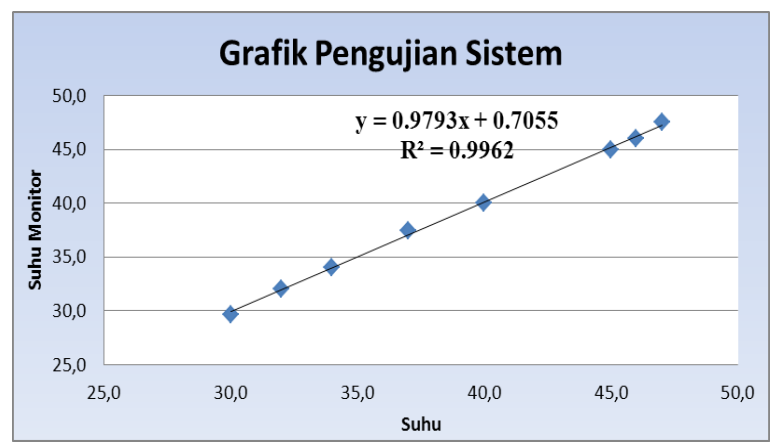

Gambar 6. Grafik pengujian sistem keseluruhan

\subsection{Pengujian Sistem Akusisi Data Pada Dua Kondisi Daerah Pengukuran}

Pengujian sistem pengukuran dilakukan di dua kondisi daerah pengukuran yaitu daerah tanpa beranomali dan daerah anomali. Yang dimaksud dengan daerah tanpa anomali adalah daerah yang tidak memiliki sistem panas bumi, pada kondisi demikian, daerah ini hanya di pengaruhi oleh radiasi matahari, sedangkan daerah beranomali adalah satu kondisi dimana terdapat sifat-sifat fisik batuan yang ada dibawah permukaan, sifat-sifat fisik batuan dapat digunakan untuk memperkirakan adanya sistem panas bumi bawah permukaan. Pengujian sistem dilakukan di tempat terpisah. Daerah tanpa anomali berlokasi di lapangan sepak bola Universitas Brawijaya, sedangkan daerah anomali berlokasi di pemandian air panas Cangar. Pengukuran temperatur pada daerah beranomali dilakukan setelah lubang dianggap stabil dan dilakukan pada pagi hari untuk menghindari pengaruh panas dari permukaan, terutama untuk daerah/lokasi yang terbuka atau terkena sinar matahari secara langsung. Pengukuran temperatur lubang dilakukan beberapa tahap, yaitu : 1) pengukuran saat sensor diturunkan; 2) pengukuran saat sensor dimasukan dalam dasar lubang sampai stabil; dan 3) pengukuran saat probe sensor dinaikkan.

\subsubsection{Daerah Tanpa Anomali}

Hasil pengukuran suhu saat probe sensor di turunkan adalah $36,6^{\circ} \mathrm{C}$ sampai $37,4^{\circ} \mathrm{C}$, sedangkan pengukuran suhu saat sensor dinaikan adalah $30,8^{\circ} \mathrm{C}$ sampai $34,0^{\circ} \mathrm{C}$. Pengujian sistem di daerah tanpa anomali dilakukan di 4 titik pengukuran. Namun karena perolehan suhu pada masing-masing titik pengukuran sama, maka diambil suhu rata-rata dari keempat titik pengukuran tersebut. Gambar 7 menunjukkan suhu rata-rata daerah tanpa anomali di Lapangan sepak bola Universitas Brawijaya. Hasil pengukuran di lokasi daerah tanpa anomali, diperoleh suhu rata-rata seperti ditampikan pada Tabel 2.

Tabel 2. Suhu rata-rata daerah tanpa anomali

\begin{tabular}{|c|c|c|c|}
\hline Sensor & $\begin{array}{c}\text { Kedalaman } \\
(\mathrm{m})\end{array}$ & $\begin{array}{c}\text { Suhu Tanpa } \\
\text { Anomali }\left({ }^{\circ} \mathrm{C}\right)\end{array}$ & $\begin{array}{c}\text { Suhu rata- } \\
\text { rata }\left({ }^{\circ} \mathrm{C}\right)\end{array}$ \\
\hline 1 & 0,5 & $30,8-32,0$ & 31,5 \\
\hline 2 & 1 & $29,0-29,7$ & 29,3 \\
\hline 3 & 1,5 & $28,4-29,0$ & 28,6 \\
\hline 4 & 2 & $27,5-28,1$ & 27,9 \\
\hline 5 & 2,5 & $27,0-27,5$ & 27,2 \\
\hline
\end{tabular}




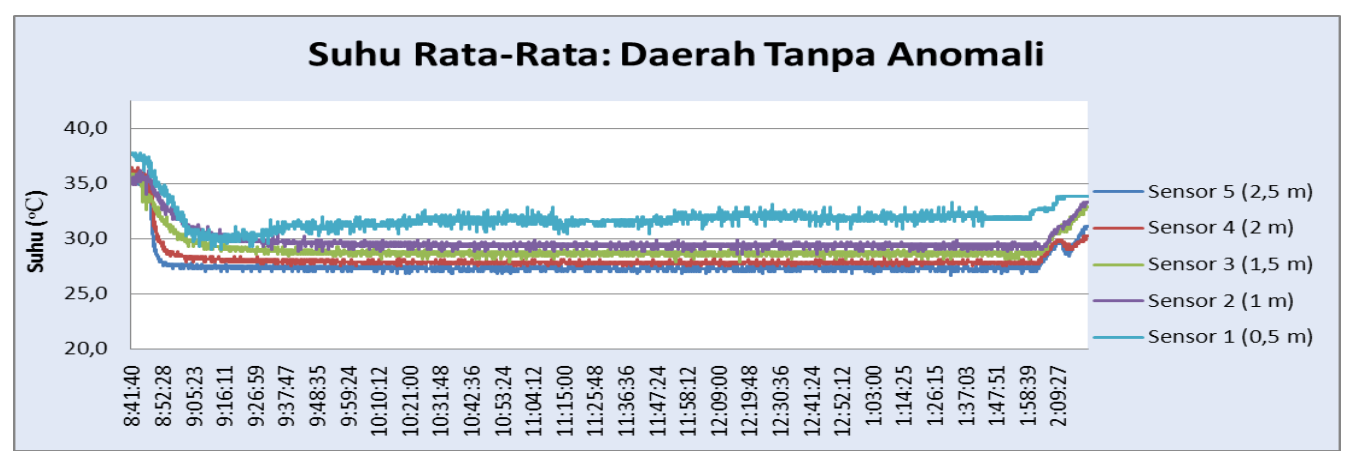

Gambar 7. Grafik tanpa anomali di Lapangan Sepak bola Universitas Brawijaya

\subsubsection{Daerah Anomali}

Pengujian sistem di daerah tanpa anomali dilakukan di 4 titik pengukuran. Penentuan lubang sebagai titik lokasi pengukuran berdasarkan pada titik lokasi yang dekat dengan sumber mata air panas sampai jauh dari sumber. Hasil pengukuran suhu rata-rata dari keempat slave, pada saat probe sensor di turunkan adalah $23,2^{\circ} \mathrm{C}$ sampai $25^{\circ} \mathrm{C}$, sedangkan pengukuran suhu saat sensor dinaikan adalah $22,3^{\circ} \mathrm{C}$ sampai $23,7^{\circ} \mathrm{C}$. Gambar 8 menunjukkan grafik daerah anomali. Selama proses pengukuran terdapat perbedaan suhu pada masing-masing slave. Pada slave 1 suhu tertinggi pada kedalaman 2,5 meter adalah $30,2{ }^{\circ} \mathrm{C}$, slave 2 suhu tertinggi pada kedalaman 2,5 meter adalah $35,6^{\circ} \mathrm{C}$, slave 3 suhu tertinggi pada kedalaman 2,5 meter adalah $39,2{ }^{\circ} \mathrm{C}$, slave 4 suhu tertinggi pada kedalaman 2,5 meter, adalah $40,3^{\circ} \mathrm{C}$. Hasil Pengukuran di masing-masing titik pengukuran pada keempat slave ditampilkan pada Tabel 3.

Tabel 3. Hasil pengukuran daerah anomali

\begin{tabular}{|c|c|c|c|c|c|}
\hline Sensor & Kedalaman $(\mathrm{m})$ & Slave 1 $\left({ }^{\circ} \mathrm{C}\right)$ & Slave 2 $\left({ }^{\circ} \mathrm{C}\right)$ & Slave 3 $\left({ }^{\circ} \mathrm{C}\right)$ & Slave 4 $\left({ }^{\circ} \mathrm{C}\right)$ \\
\hline 1 & 0,5 & 24,3 & 24,8 & 26,3 & 30,2 \\
\hline 2 & 1 & 24,8 & 26,6 & 32,6 & 36,2 \\
\hline 3 & 1,5 & 27,0 & 30,6 & 38,0 & 39,4 \\
\hline 4 & 2 & 28,6 & 33,5 & 38,2 & 40,1 \\
\hline 5 & 2,5 & 30,2 & 35,6 & 39,2 & 40,3 \\
\hline
\end{tabular}

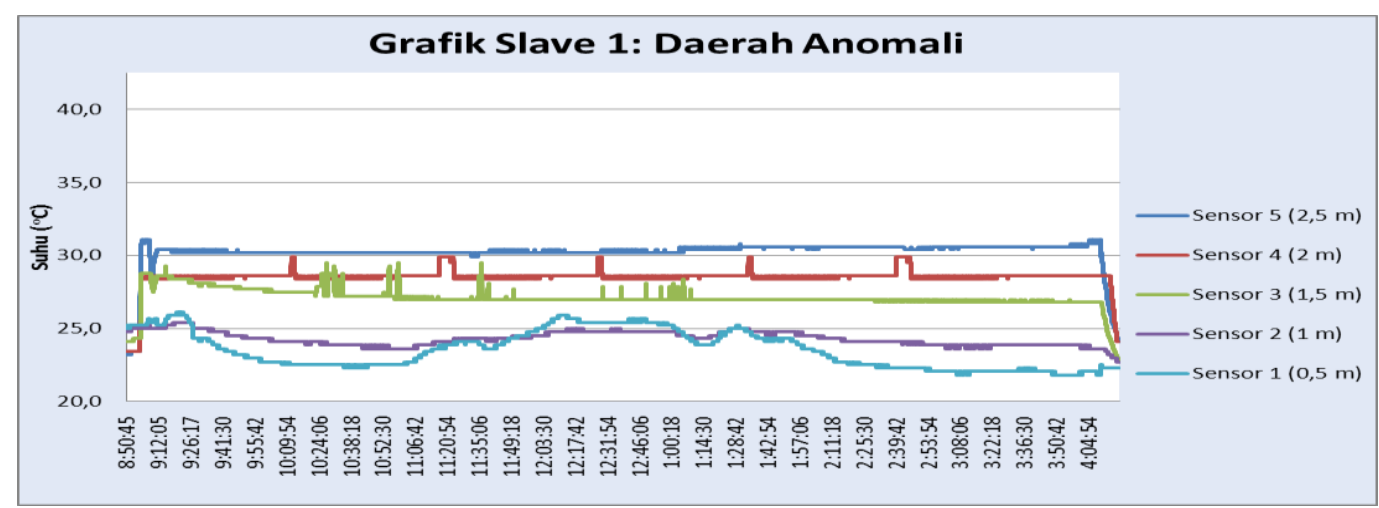

(a)

Gambar 8. Grafik anomali panas bumi di pemandian air panas Cangar. 


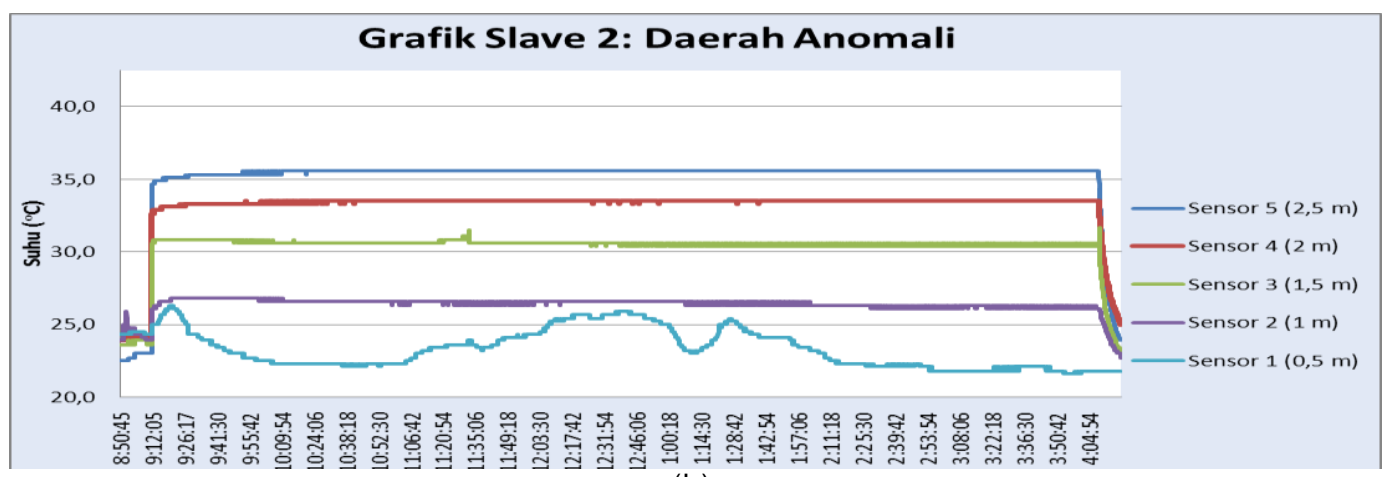

(b)

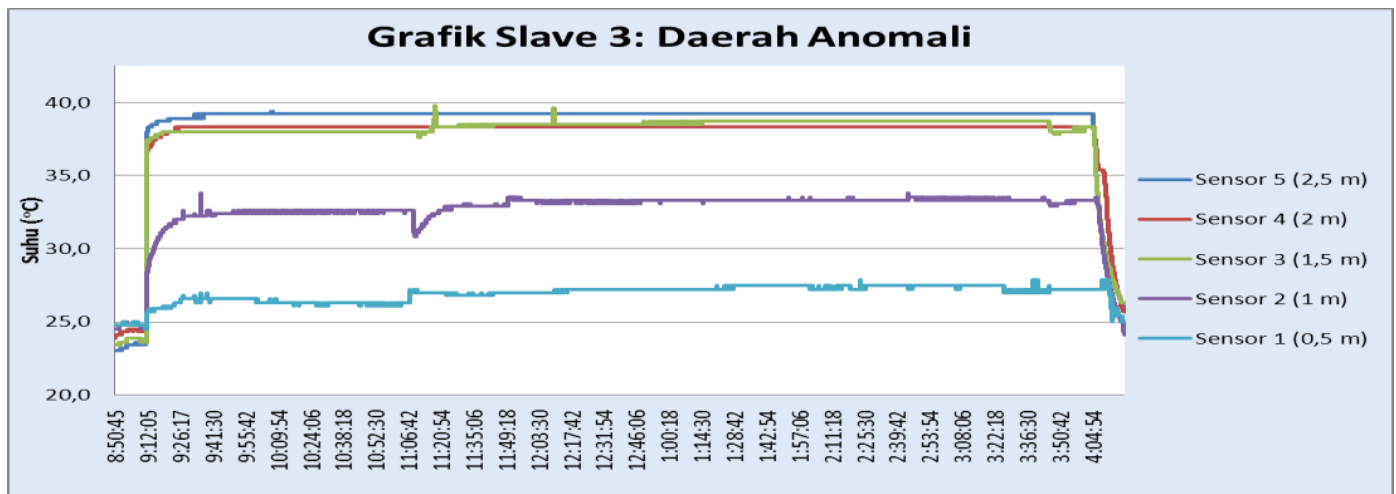

(c)

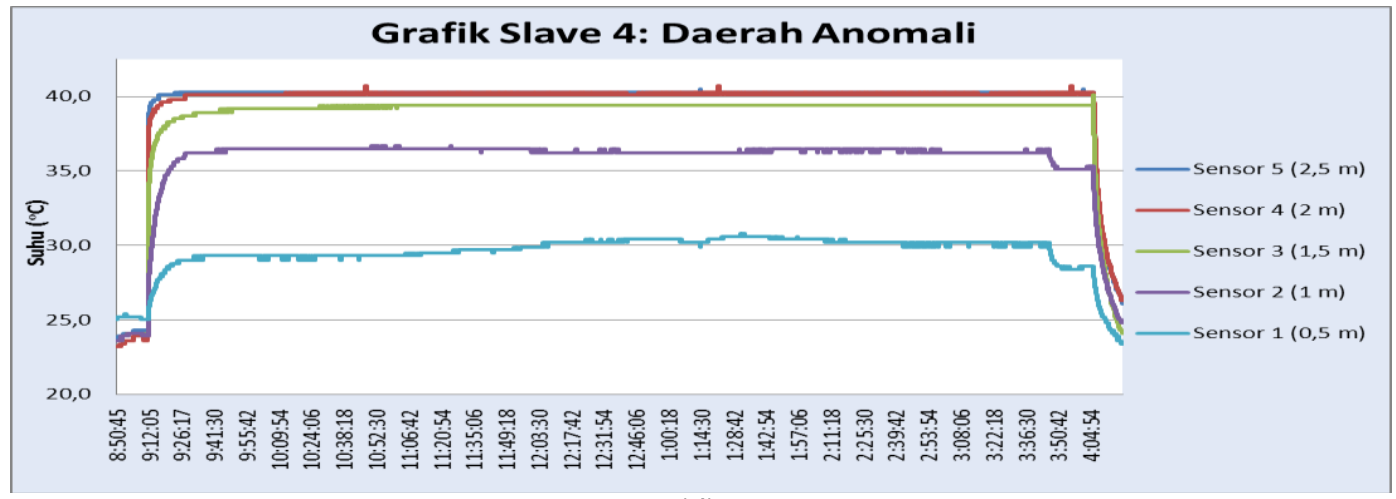

(d)

Gambar 8 (lanjutan). Grafik anomali panas bumi di pemandian air panas Cangar.

\section{Kesimpulan}

Telah dikembangkan serta diaplikasikan sistem akusisi data untuk pengukuran suhu bawah permukaan secara terdistribusi. Sistem ini mampu mengukur suhu bawah permukaan sampai kedalaman 2,5 meter, serta dapat melakukan pengukuran sekaligus pada empat titik pengukuran. Sistem yang dikembangkan meliputi RTU (unit slave) berbasis mikrokontroler menggunakan ATMega8 untuk akusisi data dari sensor suhu LM35, dan MTU (unit master) yang melayani proses monitoring pada perangkat RTU melalui sistem komunikasi data RS485. Dari hasil pengujian, alat ini mampu mengukur suhu bawah permukaan baik daerah tanpa anomali maupun daerah anomali panas bumi.

\section{Daftar Pustaka}

Arif, I. H., Refrizon, 2005. Distribusi sumber panas bumi berdasarkan survei gradien suhu dekat permukaan gunung api Hulu Lais. Jurnal Gradien. 1(2): 64-48.

Axelson, J., 1998. Serial Port Complete: Programming and Circuits for RS-232 and RS-485 Links and Networks, Lakeview Research, Madison, WI. 
Bevinton, P. R., Robinson, D. K., 1992. Data Reduction Analysis for The Phisical Sciences, $2^{\text {nd }}$ edition. Mc.Graw-Hill, New York.

Cheeke, D. 2007. Sensor Signal Conditioning. Journal Sensors \& Transducers, 82(8):1381-1388.

Data sheet LM35. 2000. LM35 Precision Centigrade Temperature Sensors. http://www. ti.com/ lit/ds/symlink/Im35.pdf. 12 Januari 2012.

Santoso, D. R., Maryanto, S., Wardoyo, P., 2012. Development of a simple \& low-cost Instrumentation system for real time volcano Monitoring. International Journal of Advances in Engineering \& Technology, 2(1): 532-542.

Sahara, I., 2011. Perancangan sistem terdistribusi untuk monitoring menggunakan DS I 820 berbasis microprosesor Tiny Inter Net interface (TINI) TBM 290. Program Studi Fakultas
Matematika dan IImu Pengetahuan Alam. Universitas Indonesia.

Santoso, D. R., 2010. A Simple Instrumentation System For Large Structure Vibration Monitoring. indonesian Journal Of Elektrical Engineerring, 8(3):265-274.

Santoso, D. R., 2005. Development of piezoelectric sensor system for strain measurement and its application to structural health monitoring. Dissertation, Graduate shool of engineering, Hiroshima University, Higashi-Hiroshima Japan.

Vitria, R. (2008), Komunikasi data serial multipoint menggunakan Teknik rs485 half duplex, Jurnal IImiah Poli Rekayasa 3(2):1858-3709. 